\title{
Results Concerning the Fusion Capacity of Some Cucurbits Grafted by Different Techniques
}

\author{
Mădălina DOLTU*), Marian BOGOESCU, Dorin SORA \\ Department of Horticultural Cultures in Protected Spaces, Research and Development Institute for \\ Processing and Marketing of Horticultural Products - Horting, 1A Intrarea Binelui Street, District 4, \\ 042159, Bucharest, Romania; \\ ${ }^{*}$ Corresponding author, e-mail: doltu_mada@yahoo.com
}

Bulletin UASVM Horticulture 72(1) / 2015

Print ISSN 1843-5254, Electronic ISSN 1843-5394

Doi:10.15835/buasvmcn-hort:10320

\begin{abstract}
The research was realized in 2014, in the Department of Horticultural Cultures in Protected Spaces at the Horting Institute of Bucharest, Romania. This aimed to study the fusion capacity of some cucurbits grafted by different techniques (one-cotyledon [1], cleft - V shaped [2] and by approach [3]) in order to emphasise the best grafting method according to survival rate data. The experience was conducted on two $\mathrm{F}_{1}$ hybrids (Cucurbita type) as rootstocks - 'TZ148' [T] and 'Shintoza' [S] and three $\mathrm{F}_{1}$ hybrids as scions - 'Mirabelle' [M] (cucumber), 'Vasko' [V] (watermelon) and 'Gina' [G] (melon). The best grafting method was with one-cotyledon, followed by cleft (V shaped) and by approach. The grafting method is very important for a successfull grafting.
\end{abstract}

Keywords: Cucurbitaceae, grafting, methods, survival rate.

\section{INTRODUCTION}

Grafting of cucurbits was briefly described in a seventeenth century book in Korea; this method is based on the fusion between scion and rootstock (Edelstein, 2004). Grafted vegetable culture is a common practice in Japan, Korea, China but it was also developed in several European countries like Spain and Italy (Lee, 1994). It also became a common production process in USA (King et al., 2008). Grafting of vegetables is new in Morocco where cucurbits grafting started in 1998 (Besri, 2008). In Romania, the grafting started after 1973 (Tomescu, 2005) and it developed because the soil borne pathogens are a serious problem, that can be avoided by using resistant rootstocks.

\section{AIMS AND OBJECTIVES}

The research has aimed to study the fusion capacity of some cucurbits grafted by different techniques. This strategy led to the choice of best grafting method. If the diameters of the plants can be correlated, grafting can be successfully performed.

\section{MATERIALS AND METHODS}

The research was conducted in a greenhouse (plastic house) of the Horting Institute of Bucharest, in 2014. The experience was conducted on two $\mathrm{F}_{1}$ hybrids (Cucurbita type) as rootstocks - 'TZ148' [T] and 'Shintoza' [S] and on three $\mathrm{F}_{1}$ hybrids as scions - 'Mirabelle' [M] (cucumber), 'Vasko' [V] (watermelon) and 'Gina'[G] (melon); the experimental variants were $[\mathrm{M}] \mathrm{x}[\mathrm{T}]$ and $[\mathrm{S}]$ / [1] - control variant, $[\mathrm{M}] \mathrm{x}[\mathrm{T}]$ and $[\mathrm{S}] /$ [2], [M] $\mathrm{x}[\mathrm{T}]$ and $[\mathrm{S}] /[3] ;[\mathrm{V}] \mathrm{x}[\mathrm{T}]$ and $[\mathrm{S}] /[1],[\mathrm{V}] \mathrm{x}[\mathrm{T}]$ and $[\mathrm{S}] /[2]$, [V]x[T] and $[\mathrm{S}] /[3]$; [G]x[T] and [S] / [1], [G]x[T] and [S] / [2], [G]x[T] and [S] / [3]; each variant contained 1000 grafted plants. After grafting, the plants were kept 7 days in plastic tunnel with $25^{\circ} \mathrm{C}$ and $80 \%$ relative air humidity prior to determine the survival rate. Three grafting methods (one-cotyledon; cleft - V shaped and by approach) were used. The grafting methods were evaluated by fusion capacity of cucurbits (survival rate), according to the Duncan test. 


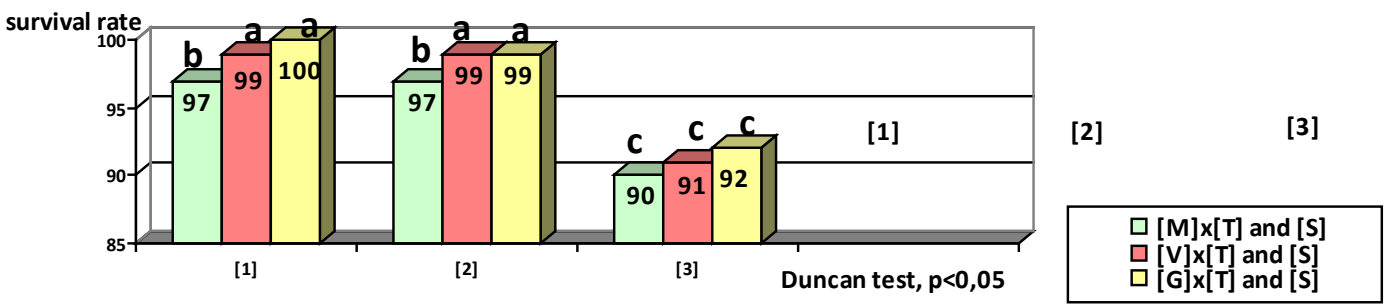

Fig. 1. Fusion capacity at cucurbits grafted by different techniques (photos source: Lee et al., 2010).

\section{RESULTS AND DISCUSSION}

The grafting method has influenced the survival rate. The survival rate was determined 7 days after grafting, on plants with one true leaf, 4-5 $\mathrm{mm}$ diameter and 5-7 $\mathrm{cm}$ height. Some differences were obtained between the variants (Fig. 1).

The best grafting methods were with onecotyledon and cleft ( $\mathrm{V}$ shaped), followed by approach. Duncan test shows a significant difference between grafting techniques, even though, there was no significant difference between grafting with one-cotyledon and cleft (V shaped) grafting. The species/cultivar did not influence the grafting, no significant difference between scions and rootstocks being revealed. In the specialty literature, the results concerning the best grafting method are contradictory. Vuruskan and Yanmaz, 1991, have reported different results concerning the survival rate according to the grafting method, respectively $83.3 \%$ with cleft grafting, $69.7 \%$ with whip and tongue grafting and $43.7 \%$ with lateral perforation techniques; there were no significant differences between rootstock and scions. Rojas and Riveros, 2001, have reported similar results concerning the grafting techniques, only cleft grafting being lower. Mohamed et al., (2014) had the best result with by tongue approach grafting method.

\section{CONCLUSION}

The best grafting technique was with onecotyledon, followed by cleft (V shaped) and afterwards by approach; the species/cultivar did not influence the grafting. The grafting method is very important for a successfull grafting.

\section{REFERENCES}

1. Besri M (2008). Cucurbits grafting as alternative to Methyl Bromide for cucurbitsproduction in Morocco. Annual International Research Conference on Methyl Bromide Alternatives and Emissions Reductions, Orlando, Florida, 60:1-6.

2. Edelstein M (2004). Grafting vegetables-crop plants. Pros and Cons. Acta Hortorticulture, 659:235-238.

3. Lee JM (1994). Cultivation of grafted vegetables I: current status, grafting methods and benefits. Hortscience 29:235-239.

4. Lee JM, Kubota C, Tsao SJ, Bie Z, Echevarria PH, Morra L, Oda M (2010). Current status of vegetable grafting techniques, automation. Science Horticulturae. 127 Iss. 2:93-105.

5. King SR, Davis AR, Liu WG, Levi A (2008). Grafting for disease resistance. HortScience, 43:1673-1676.

6. Mohamed FH, Abd El-Hamed KE, Elwan MWM, Hussien MNE (2014). Evaluation of different grafting methods and rootstocks in watermelon grown in Egypt. Scientia Horticulturae, 168:145-150.

7. Tomescu A, Alexandri A (2005). Technology for combating phytopathogenicfungi that cause vascular wilts at solanaceous and cucurbits vegetable species. AGRAL Project, 3396/2003.

8. Vuruskan MA, Yanmaz R (1991). Effects of different grafting methods on the success of grafting and yield of eggplant/tomato graft combination. Acta Hortorticulture (ISHS) 287:405-410.

9. Rojas L, Riveros F (1999). Effect of grafting methods and seedling age on survival and development of grafted plants in melon (Cucumis melo). Agricultura Tecnica, 61:262-274. 